\title{
Assessment of the Key Drivers of Forest Cover Change and Its Associated Livelihood Impacts in Yabello District, Borana Zone, Ethiopia
}

\author{
Sisay Taye Gifawesen \\ Department of Agroforestry, Oromia Agricultural Research Institute, Yabello Pastoral and Dry Land Agriculture Research Center, Yabello, \\ Ethiopia
}

\author{
Email address: \\ gemsis2018@gmail.com
}

\section{To cite this article:}

Sisay Taye Gifawesen. Assessment of the Key Drivers of Forest Cover Change and Its Associated Livelihood Impacts in Yabello District, Borana Zone, Ethiopia. International Journal of Sustainable and Green Energy. Vol. 8, No. 1, 2019, pp. 1-11.

doi: $10.11648 /$ j.jirse.20190801.11

Received: January 9, 2019; Accepted: February 1, 2019; Published: February 25, 2019

\begin{abstract}
Land-use/land-cover change is a significant cause, or forcing function of global change and the medium through which many human responses to global change will occur. Analyzing the key drivers of forest and land use land cover change (LULC) is an effective way of assessing the impacts of land use/land cover (LULC) changes in ecosystem function. A study was conducted to assess the key drivers of forest cover change and land use land cover change (LULCC) and its associated impacts on the livelihoods of the study area. About 128 respondents were interviewed to assess possible causes of the forest cover change and LULCC. The result of survey assessment indicated that recurrent drought (100\%), wood extraction (100\%), increased in human population size (99.2\%), infrastructural expansion (settlement expansion and road construction) (81.3\%), policy and institutional factors (70.3\%), economic factors (64.9) and expansion of cultivation (32.1\%) and social-cultural factors $(26.6 \%)$ were largely responsible for the observed LULC changes in the study area. Consequently, change in forest cover and land use, land cover were affected different livelihood strategies of the communities like; human resources, forest production, crop and livestock production, financial and their social capital resources. Thus, collaborative forest management arrangements with the local communities and improved law enforcement strategies were essential to ease the present human influence on the natural forest and enhance sustainable management.
\end{abstract}

Keywords: Forest Covers Change, Drivers, Livelihood

\section{Introduction}

Nature and more importantly, human beings are greatly influencing the environment including land use, land cover and forest cover which is dynamic in nature [1]. Forest transitions begin during a period of deforestation. Initially, forests decline in extent as growing numbers of cultivators, with help from loggers, clear forested lands and convert them into fields in order to meet growing demands for food and fiber from human populations that reside, increasingly, in cities [2]. Accordingly, the world's natural forests decreased by 16.1 million hectares per year on average during the $1990 \mathrm{~s}$; that is a loss of $4.2 \%$ of the natural forest that existed in 1990 [3]. Whereas, forests cover slightly more than 4 billion ha (31\% of the world's total land area) and correspond to an average of 0.6 ha per capita [4]. However, about 13 million ha of forests was converted to other uses or disappeared as a result of natural phenomena each year during the past decade [4].

Long-term human influences are considered to be the primary cause of unsustainable forest exploitation in Ethiopia and subsequently resulted in serious environmental degradation in the highlands of the country and response to recurrent droughts [5]. At the turn of the twentieth century, $40 \%$ of Ethiopia was covered by various types and densities of forest. It was reduced to $16 \%$ of the land area in the $1950 \mathrm{~s}$ and shrank further to $2.7 \%$ in the $1990 \mathrm{~s}$ [6]. On the other hand, forest resources of Ethiopia were reported with forest canopy cover of 10-30\% [4]. Accordingly, Ethiopia's forest cover is 12.2 million ha $(11 \%)$, and it further indicated that 
the forest cover shows a decline from 15.11million ha in 1990 to 12.2 million ha in 2010 , during which $2.65 \%$ of the forest cover was deforested. In a similar manner, in pastoral rangeland systems of southern Borana, there was the continuous decline in open shrub and tree savanna areas from $45 \%$ in the 1976 to $9 \%$ in the $2012(-36 \%)$ and forest land declined by $6 \%$ from 1976 to 2012 [7].

Driving forces of land use land cover change emerged as an important topic on the international research agenda in the 1970 s, as a consequence of the concern for the impact land use land cover changes might have on regional and global climate [8]. Factors driving LULC change include an increase in human population and population response to economic opportunities. Human population growth pressures are expanding the area of land uses such as agriculture and settlement into natural habitats in all parts of the world to meet the demand for food and housing [8].

Despite the social and economic benefits of LULC change, this conversion of LULC usually has an unintended consequence on the natural environment [9]. These land-use changes have led to deforestation, further aggravating fragmentation of remaining forest habitats [10]. For example, biodiversity loss due to deforestation results in a decline in ecosystem integrity and may impact hydrological processes, leading to flooding and soil erosion [11]. Land cover dynamics, particularly deforestation has become a global concern, with dramatic implications for human livelihood systems. It is one of the major topics of current global change studies [12].

Besides deforestation, another major cause of land-use land-cover change, particularly in Ethiopia, was the droughts of the 1970s and early 1980s [13]. Urbanization also affects land change elsewhere through the transformation of urbanrural linkages. Accordingly, settlement areas with permanent housing were reported increased while, results for woodland vegetation decreased [14]. Furthermore, institutional drivers like lack of good property right governance and formal policies and their effects on biodiversity, lack of awareness of property rights (rights and responsibilities to natural resources in the use of environmental goods and services are affected the forest cover changes [15]. These driving forces represent the interaction between biophysical and societal processes over time, and they reflect the interaction between local and national scales [16]. Understanding the complexity of land-use and land-cover (LULC) changes and their driving forces and impacts on human and environmental security is important for the planning of natural resource management and associated decision making [17].

Conversions of land from one use to another have become recognized as major causes of global environmental changes and also local land use land cover dynamics. Such local-level dynamics play a significant role in determining the health of an ecosystem at the micro level. Borana Plateau has markedly changed in terms of forest cover and land use, land cover in recent decades, and Yabello district has indeed changed greatly in terms of land use/cover; dramatic declines were noted in the extent of grasslands and forest land, while croplands increased fivefold, and bushed-grasslands and bush lands both increased substantially [18]. Borana zone is one of the areas in which woodlands, and shrub lands found in southern parts of the country. These woodlands, and shrub lands forest resources currently are under problem due to human pressure for construction and firewood, over grazing and climate change (recurrent drought). Moreover, forest cover of Borana decreased from $1.5 \%$ in 1986 to $1.2 \%$ in 2002, which is decreased by 6511 ha [19]. Juniperus procera forests naturally found in the Zone are also currently disappearing due to distraction for construction and firewood and patch of woodland tree species in the area are drying and others are distracting. Accordingly, continuous declining of open shrub and tree savanna areas was reported from $45 \%$ in the 1976 to $9 \%$ in the $2012(-36 \%)$ and forest land declined by $6 \%$ from 1976 to 2012 in pastoral rangeland systems of Borana [7]. This condition needs to be studied to understand the situation based on empirical evidences.

It is, therefore, important to assess the major drivers of forest conversion and its associated livelihood impacts to the livelihood of the study area as it can help to design more effective forest management strategies and policies for climate resilient green economy (CRGE) plan that the country is currently following and also provides necessary supporting data for the pastoralists, researchers, GO's and NGO's).

\section{Materials and Methods}

\subsection{Description of the Study Area}

The study was conducted in Dharito and Obda kebele (PA) located in the Yabello district in Borana range land of southern Oromia. Yabello district is situated in a Borana zone in the Oromia National, Regional State at $570 \mathrm{~km}$ south of Addis Ababa. The total land area of the study sites (Dharito and Obda) is $270.0981 \mathrm{~km}^{2}$ and lies between 1350 and 1800 m. a.s.l [20]. The study area lies between $4^{0} 38^{\prime} 30^{\prime \prime} \mathrm{N}$ to $4^{0}$ $57^{\prime} 0 " \mathrm{~N}$ and $38^{\circ} 2$ ' 0 " $\mathrm{E}$ to $38^{\circ} 16^{\prime} 30^{\prime \prime} \mathrm{E}$. The district and the peasant associations (PAs) that the study conducted were illustrated below in (Figure 1). Yabello district has a bi-modal rainfall pattern with the main rainy season (Ganna) between March and May with the peak in April [20]. The short rainy season (Hagayya) extends from September to November with a peak in October. The mean annual rainfall of the zone ranges from $352 \mathrm{~mm}$ at the southern part to $605 \mathrm{~mm}$ to the northern part of the zone. The mean annual rainfall is 587.2 $\mathrm{mm}$. The mean annual temperature varies from $15-24^{\circ} \mathrm{C}$ and shows little variation across the seasons [20].

The geology of the study area is dominated by $40 \%$ quaternary deposits, $38 \%$ basement complex formations, and $20 \%$ volcanic as cited [21]. Borana range land comprise of three main soils, 53\% red sandy loam soil, 30\% black clay and volcanic light colored silty clay and $17 \%$ silt [20]. The rangelands of the district as a whole are communal land except some areas, which are owned by government organization (ranches, sanctuaries), and investment areas 
[22]. Five major land use/cover patterns, namely grassland cover, woody vegetation cover, cultivated land; settlement and bare land were identified in the district [19].

Plant communities on flat and hilly plains of central Borana Plateau consist of a diverse mixture of woody and herbaceous vegetation [20]. Accordingly, four plant community types were described, namely: evergreen and semi evergreen bush land and thickets, rangeland dominated by shrubby Acacia, Commiphora and allied genera, and dwarf shrub grassland to shrub grassland [21]. The best forage sources are native species of grasses, woody plants and stands of Acacia species [23]. The total human population of the zone is about 1,192,649 (601,649 males and 591,000 females) while the population of Yabello district is about 128,762 (64,692 Male and 64,070 F [24]. The livestock population in the zone by species is $1,081,553$ cattle, 343,674 sheep, 876,139 goats, 874 horses, 2,102 mules, 73,762 donkeys, 75,622 camels, 689,154, poultry and 68,953 beehives [25].

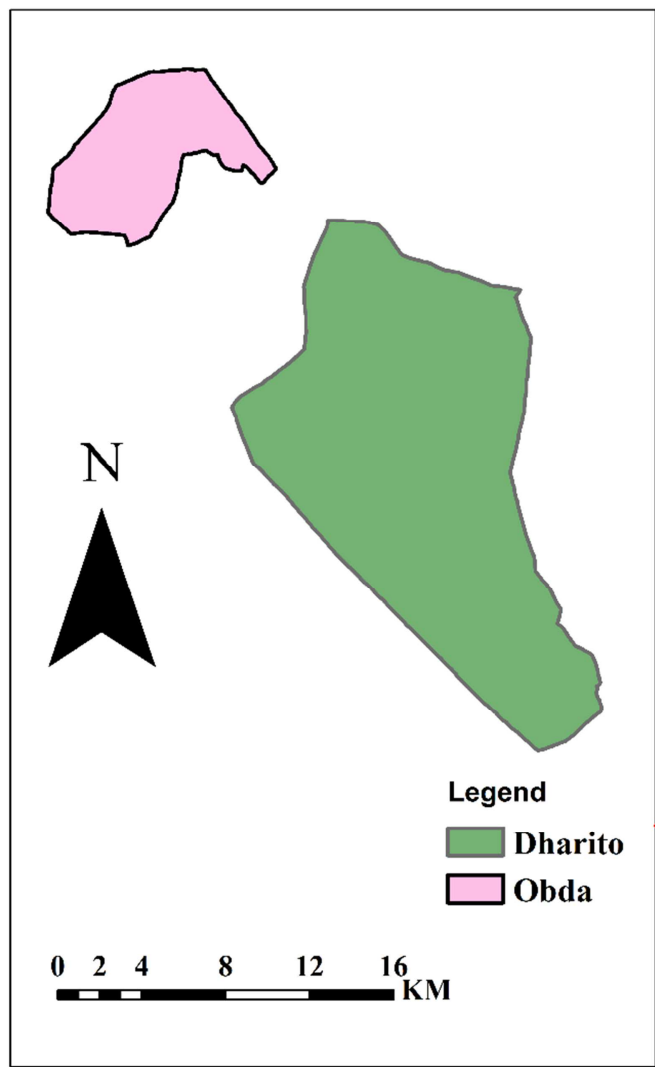

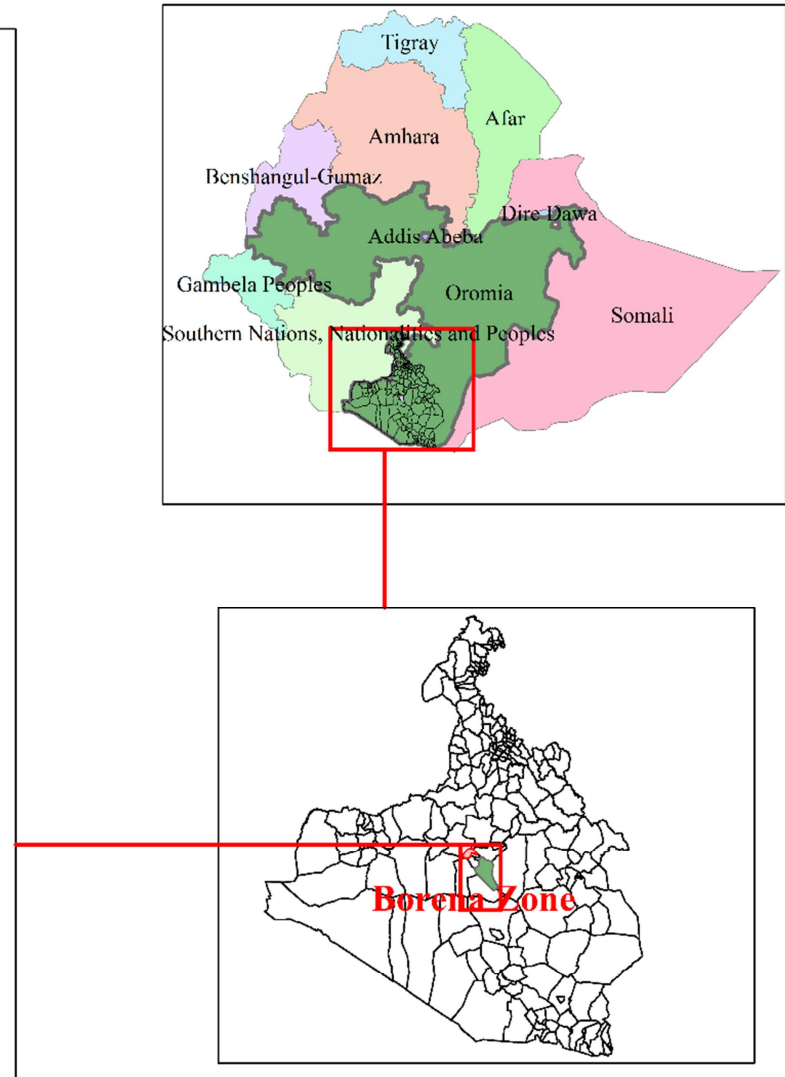

Figure 1. Location of the study area.

\subsection{Methods of Data Collection}

\subsubsection{Types and Sources of Data}

Discussions and interviews with experts of zonal and Woreda office agriculture and NGOs working in the area as well as key informants from Borana pastoralists were held on the study research questions. Then a reconnaissance survey was conducted with the purpose of assessing, identifying and selecting the land use/land cover and forest areas representing forests of Yabello district. Finally, based on the above criteria two study sites Dharito and Obda Kebele were selected to assess drivers and impacts of forest cover change on pastoralist livelihood. The study largely encompasses household socioeconomic survey and all data were collected in March and May, 2017. Both primary and secondary data sources were used.

\subsubsection{Socioeconomic Survey}

The sample size of the study area was determined using
Kothari formula shown in below [26]. Simple random probability sampling was used for the determined sample size. The Kothari sample size formula for determining sample size was become;

$$
n=\frac{Z^{2} \cdot p \cdot q \cdot N}{e^{2}(N-1)+z^{2} \cdot p \cdot q}
$$

Where; $\mathrm{n}=$ sample size, $\mathrm{Z}=95 \%$ confidence limit (interval) that is 1.96 given or constant, $\mathrm{P}=0.1$ (population proportion to be included in the sample that is $10 \%)=$ it depends, $q=$ None occurrence of event $=1-p=1$ 0.1 that is (0.9), $\mathrm{N}=$ total number of (household) found in the study area and $\mathrm{e}=$ level of accuracy or sampling error (Where, $\alpha=0.05$ ).

Following the formula, 128 household heads were used for data collection through a structured questionnaire. The 
sample size is proportional to the total member of household size of each Kebele (Table 1). About six focus group discussions (FGD); four in Dharito and two in Obda Kebele which include, key-informants (Kebele representative, elders, community leaders) having 6-12 participants were established for this study. Semistructured questionnaire were used to interview all the sampled 128 households and focus group discussions were carried out on issues such as possible causes of the forest cover change and land use/land cover changes, drivers and its challenges to pastoral community.

Table 1. Total population and determined sample size of the study area.

\begin{tabular}{lll}
\hline Kebele & Total household head number & Sample size \\
\hline Dharito & 1265 & 93 \\
Obda & 484 & 35 \\
Total & 1749 & 128 \\
\hline
\end{tabular}

\subsection{Data Analysis and Preparation}

Possible causes of the forest cover change and land use, land cover changes, drivers and its challenges to pastoral community obtained through structured questionnaire and key informant interviews were analyzed using SPSS version 20 Statistical Software. The results of interviews were summarized and discussed using descriptive statistics such as frequency and percentages and tables.

\section{Results and Discussion}

\subsection{Socioeconomic Profile of Sampled Respondents}

\subsubsection{Respondents Sex and Occupations}

The result showed that out of the total sampled household head about $90.60 \%$ were male headed and $9.40 \%$ were female Headed (Table 2). Thus, more than $81.20 \%$ of male's household head $(\mathrm{HH})$ than female HH. The reason was, during the survey time it was dry period and women were busy to searched water and hay for feeding their livestock. Women also didn't remember the trends of the past as much as a man as the study was much related to the 30 year trends. With regards of pastoralists' livelihood, the study revealed all of the respondents $(100 \%)$ were practicing agro pastoralists as their main economic activities. This showed that there is no pure pastoralist who's their livelihood depend on sole livestock rather mixed livelihood/agro pastoralists (crop and livestock rearing). Besides their main economic activity (agro pastoralist), there were different additional activity that household participating to perform their livelihood. Thus, out of the total sampled $\mathrm{HH}$ around $10.20 \%, 6.20 \%$, $1.60 \%, 7.80 \%$ and $2.30 \%$ were practicing petty trade, charcoal selling, handcraft, labor work and employed as guard respectively (Table 2 ).

Table 2. Respondents sex, main and additional economic activities.

\begin{tabular}{|c|c|c|c|}
\hline \multirow{2}{*}{ Variables } & & \multicolumn{2}{|c|}{ Overall $(\mathrm{N}=128)$} \\
\hline & & Freq. & $\%$ \\
\hline \multirow{2}{*}{ Sex } & Male & 116 & 90.60 \\
\hline & Female & 12 & 9.40 \\
\hline \multirow[t]{3}{*}{ Main occupation } & Agro-pastoralist (crop and livestock production) & 128 & 100 \\
\hline & Petty trade & 13 & 10.2 \\
\hline & Charcoal sells & 8 & 6.2 \\
\hline \multirow[t]{2}{*}{ Additional activity } & Handcraft & 2 & 1.6 \\
\hline & Guard & 3 & 2.3 \\
\hline
\end{tabular}

Source: Field survey, 2017.

\subsubsection{Respondents Age, Family Size, Land Size and Duration They Live in the Study Area}

In study areas the overall mean age of respondent households' head was found to be almost $63.10 \pm 1.10$ where the ages of respondent in study areas range from 42 minimum years to 97 maximum years (Table 3 ). The overall mean of family size and duration of the household's head stays in the area was found to be $8.21 \pm 0.25$ and $53.03 \pm 1.26$ respectively, where the range of family size and duration of the household head stays in the study areas were ranged from 2 minimum to 19 maximum and 30 minimum to 88 maximum respectively (Table 3 ). In a similar manner, the overall mean of land holding size of the $\mathrm{HH}$ was $1.78 \pm 0.08$ with a range of 0.5 minimum and 6 maximum.

Table 3. Respondents age, family size, land size and duration they live in the study area.

\begin{tabular}{llll}
\hline \multirow{2}{*}{ Variables } & Overall (Mean \pm SE) & Range \\
\cline { 2 - 4 } & & Min \\
\hline Age & $63.10 \pm 1.10$ & 42.00 & 97.00 \\
Family size & $8.21 \pm 0.25$ & 2.00 & 19.00 \\
Year of household live in the area & $53.03 \pm 1.26$ & 30.00 & 88.00 \\
Total land size & $1.78 \pm 0.08$ & 0.50 & 6.00 \\
\hline
\end{tabular}

Source: Field survey, 2017. 


\subsection{Drivers of Forest Cover Change and Land Use Land Cover Change}

Susceptibility to forest degradation is understood that the forest resources can be influenced or degraded by human activities [27]. In reality, forest resources are degraded not only by human activities but also due to other natural factors too. However, in this study, human activity were taken into consideration. Accordingly, direct and indirect forest cover change and land use land cover change causes were identified. Thus, agricultural expansion, wood extraction/forest conversion and infrastructural and settlement expansion were identified as direct causes of forest cover change and land use land cover change while economic factors, policy and institutional factors, social factors, demographic factors and drought, which was common across Borana range lands were indirect causes of the forest cover and land use land cover of the study area (Table 4). Therefore, these above listed causes together were leading to forest cover change, in particular and land use land cover change in general.

\subsubsection{Direct Drivers of Forest Cover Change}

\section{i. Agricultural expansion}

The result showed that cultivated land was found to be one of the leading causes of forest cover and land use/cover change practiced in the study area. Accordingly, agricultural expansion accounts for forest cover change of the study area by $32.1 \%$ (Table 4 ). This indicates that, agricultural farming was still going on in such drought limited area to improve food security for their subsistence farming however, their crop productivity was reduced. Therefore, in combination with other factors, agricultural expansion leads to forest cover change and land use cover change of the study area.

The finding was similar to a study reported that agricultural expansion was found to lead to deforestation in 146 out of 152 cases (96\%) [28]. Another study, stated that there is a marked increase in cultivated land in some of the Borana rangelands while in the other sites there is a slight reduction [14]. Thus, expansion of cultivation practices upon rangelands has resulted in significant loss of vegetation biomass and soil erosion, thereby precipitating rangeland degradation. Another finding also states that about 59,000 ha is converted to agricultural land per year in Ethiopia at the expense of the surrounding forests [29]. Besides, another study also stated that mostly from north to southwest part of the country around $7 \%$ of forest converted to cropland and settlement from 1999-2007 and this is took place within and between states [30]. For example; in Amhara state since 2003, 166,204 Household heads has been resettled. Similar results were reported that agricultural expansion has been a significant factor in the decline of forest coverage in the northeastern Cambodian province of Ratanakiri [31].

\section{ii. Wood extraction/forest conversion}

Wood extraction is by far, the leading forest cover change and LULC change of the study area which is associated with nearly all deforestation cases $100 \%$ (Table 4 ). This is because of the pastoralists were extracting the forest and forest products for different purposes. Many of the household were extracting forests for construction purposes (house and fence), fuel wood, and charcoal production. Hence the majority of the households were extracting forests for a combination of (fuel wood extraction, charcoal production and wood for construction). Fuel wood harvesting and charcoal production were both for rural as well as urban uses. Another study was also reported that the extraction of wood or timber, in combination with other proximate causes and factors, is lead to deforestation in 102 out of 152 cases (67\%), commercial wood extraction (52\%), while the impact of fuel wood extraction (28\%), pole wood extraction (20\%), and charcoal production $(10 \%)$ tend to be lower [28]. The study in Chencha and Arbaminch areas, states that hotels and universities use wood for fuel as it is cheaper than electricity [32]. Hence, this resulted in forest degradation and change in forest cover as well as land use land cover change.

\section{iii. Infrastructural and settlement expansion}

Infrastructure expansion (construction of roads) and settlement expansion are also the most frequently reported activities causing forest conversion of the study area. Accordingly, about $(81.3 \%)$ of the respondents deal with infrastructural expansion and settlement and resettlement expansion was one of the driving forces of forest cover change and land use land cover change. However, road construction is reportedly less associated with deforestation in the study area (Table 4). Thus, settlement expansions together with other, infrastructural improvements were holding the largest share in deforestation.

The result is similar to the study reported that settlement areas with permanent housing increased and results for woodland vegetation decreased [14]. Another similar report indicated that the expansion of rural, semi-urban and urban settlements reportedly contributes to deforestation in slightly more than one fourth of all cases (27\%) [28]. Furthermore, another study also stated that expanding cities and towns require land to establish the infrastructures necessary to support a growing population, which is done by clearing the forests $[33,34]$.

\subsubsection{Indirect Drivers of Forest Cover Change}

\section{i. Economic factors}

Economic factor was also found as one of the causes of forest cover change as peoples were using the forests for economic purposes specifically during dry season; at the time of hungry period. When the demand forests were increased in the market, they were cutting and selling the forest and forest products to generate the income used for their livelihood. Likewise, when the price of the crop was increased in the market, they also start to sell the forests to buy food crop for their family. The action of using forest for this purpose during such condition was also led to a gradual decrease in forest cover change. Generally the pastoralists were trying to sell forests for economic purposes, both at the time of increased access to markets (buying/selling) and increased access to crop price. Accordingly about $64.9 \%$ of the sampled households were using the forests for economic 
purposes during such conditions (Table 4). This study is similar with reports indicated that economic factors are major forces of causing tropical deforestation (81\%) [35].

\section{ii. Policy and institutional factors}

The study had shown policy and institutional factors as one of the major factors causing forest cover change and land use land cover change. In this case, about $70.3 \%$ of the sampled respondents agreed with the subject (Table 4). These, policy failures such as corruption or mismanagement in the forestry sector and weak PFM were the important drivers of forest cover change of the study area. There is a PFM and also a forest conservation group in the study area, however, their management of natural resource was weak. Moreover, during the assessment of the research the respondent discusses that PFM is not inclusive of all communities, and even some members of the forest user group reported that they are less satisfied to the advantage they got from PFM as there is less transparent in deciding benefit sharing and this leads people to extract forests that plays an important role in forest decline. This continual action was leading to extraction of forests without any limitation and allows for the gradual degradation of forest cover of the study area. Institutional factors also drive many cases of deforestation (78\%) in tropical deforestation, which was similar to this finding [35]. Another study also stated that the uncertain land tenure system, leading to lower investment by the people and lack of ownership stimulates illegal logging and the so called tragedy of commons [32]. Thus, weak policy implementation of land use, low capacity of forest institutions, land use conflict and policy discrepancy are aggravating forest losses. Additionally, implementation of investment and settlement policies without assessing environmental impact is also a major problem [36]. In a similar manner, another study also indicated that, changes in policies that govern natural resources have influenced the land use change and the expansion of cultivation [14].

\section{iii. Social-cultural factors}

Social-cultural factors were also found as one of the drivers changing forest cover of the study area. Public attitudes such as unconcern for forests due to low morale and frontier mentalities and other unconcern or lack of basic psychological; values such as disregard for nature and to a lesser degree; beliefs or disregards about the environment are associated to factors causing forest cover change/deforestation. Accordingly about $26.6 \%$ of the pastoralist responded that forest cover change is due to changes in public factors (Table 4). This is due to attitudes of public unconcern towards forest environments. The finding was showed, that cultural or socio-political factors, in combination with other drivers, are found to be involved in 101 out of 152 (or $66 \%$ of all) causes of deforestation [28].

\section{iv. Demographic factors}

Population growth was reported to be one of the main driving factors of forest and land use land cover change of the study area. This was most probably related to anthropocentric factors causing LU/LCC and forest cover change. As a result, immigration, population growth and density were causing forest cover change and most of the respondents $(99.2 \%)$ agree that population growth was a potential driver of forest cover change (Table 4).

Several researches were reported that demographic related factors like: population growth and density were the major factors causing forest cover and LULC change. Accordingly, the reports from [37] in the Awash national park says most respondents (74\%) agree that population growth was a potential driver of the land use land cover change. Moreover, an increase in the immigration of the local people of the pastoralists also increases the competition on natural resource like trees for house construction, fuel wood and pasture land/grass land. Similarly, another study stated that in Awash National Park Management Plan, the immigration of the Ittu people towards Fentale district has caused increased competition over resources and contributed to the observed LULC changes [38]. Likewise, among demographic factors $(61 \%)$, only in-migration of colonizing settlers into sparsely populated forest areas, with the consequence of increasing population density there shows a notable influence on deforestation [35].

\section{v. Drought}

In Borana zone, prolonged and recurrent drought is the most typical corrupted events of climate change. Remarkably, drought cycle has been shortened than earlier that increase its risk [39]. Drought impacts include decreased availability (water shortages) which leads to decreased in pasture availability and death of livestock, crop failure and food insecurity. Thus, all impacts bring increased competition over scarce resources like forest resource for the fodder of their livestock in Borana [40]. The recent study area was one of the dry land area found in southern regions of Ethiopia with a huge climatic problem challenging the livelihood of pastoralists. Therefore a greater shortage of rainfall was assessed as one of the major factors causing forest cover change and LU/LCC of the study area. Thus, all the sampled pastoralist $100 \%$ were agreed lack of rain falls, affecting the forest cover change of the study area (Table 4). Hence, the long drought season brings shortage of grass/kaloo for livestock and this leads many of the pastoralists to cutting trees for feeding their livestock. This measure, however, brings a change in forest cover and land use/land cover. Similar study stated that pasture creation for cattle ranching is a striking cause of deforestation reported almost exclusively for the lowland of Borana range lands [40].

Another study confirmed that inhabitants interviewed in the study areas perceived land use and land cover changes to be driven by the interplay of recurrent drought, loss of pasture, food insecurity, and decline income which then resulted in forest deforestation [14]. 
Table 4. Major factors causing of forest cover change and LULC change.

\begin{tabular}{|c|c|c|c|}
\hline \multirow{2}{*}{ Forest cover change causes } & & \multicolumn{2}{|c|}{ Overall $(\mathrm{N}=128)$} \\
\hline & & Freq. & $(\%)$ \\
\hline \multirow{3}{*}{ Direct causes } & Agricultural expansion & 41 & 32.1 \\
\hline & Wood extraction & 128 & 100 \\
\hline & Infrastructural expansion & 104 & 81.3 \\
\hline \multirow{4}{*}{ Indirect causes } & Economic factors & 83 & 64.9 \\
\hline & Policy and institutional factors & 90 & 70.3 \\
\hline & Social-cultural factors & 34 & 26.6 \\
\hline & Drought & 128 & 100 \\
\hline
\end{tabular}

Source: Field survey, 2017.

\subsection{The Impact of Forest Cover Change on Rural Livelihoods}

\subsubsection{Impact on Human Resource Asset}

The current study revealed that, change in forest cover and entire land use system due to climate related factors and wood extraction are affecting human resources that are important to people's livelihoods; including education, occupation and human labor (Table 5). Accordingly, the respondents of the study area revealed that their education status was decreasing through 1986 to 2016 period. This showed that increased migration resulting from droughts and conflicts leads to increased school dropouts. The respondents' occupations were agro pastoralists in all periods. However, their production was declined and also some of them were employed as guard in recent time. Therefore, reduction in their productivity shifts some people to be employed as a guard and practice other different economic activities. Similarly, the human labor productivity and capability to undertake different activities of the respondents have been decreasing for the past 1986-2016 due to the changes. A similar study in Borana and Somali was stated that drought due to land use land cover change is affecting human resources that are important to people's livelihoods, including education, health, human labor and various abilities [40].

Table 5. Trends of human resource asset of the respondents.

\begin{tabular}{|c|c|c|c|c|c|c|c|}
\hline \multirow{2}{*}{ Variables } & & \multicolumn{2}{|c|}{ 1986-1996 Overall $(\mathrm{N}=128)$} & \multicolumn{2}{|c|}{ 1996-2006 Overall $(\mathrm{N}=128)$} & \multicolumn{2}{|c|}{ 2006-2016 Overall $(\mathrm{N}=128)$} \\
\hline & & Freq. & $\%$ & Freq. & $\%$ & Freq. & $\%$ \\
\hline \multirow{4}{*}{ Household educational level } & Increasing & 21 & 16.4 & 79 & 61.7 & 59 & 46.1 \\
\hline & Decreasing & 43 & 33.6 & 29 & 22.7 & 65 & 50.8 \\
\hline & The same & 4 & 3.1 & 8 & 6.3 & 3 & 2.3 \\
\hline & Uneducated & 60 & 46.9 & 12 & 9.4 & 1 & .8 \\
\hline \multirow{2}{*}{ Household occupation } & Agro-pastoralist & 128 & 100 & 128 & 100 & 128 & 100 \\
\hline & Guard & 0 & 0 & 0 & 0 & 3 & 2.3 \\
\hline \multirow[t]{2}{*}{ Household labor activity } & Decreasing & 90 & 70.3 & 30 & 23.4 & 46 & 35.9 \\
\hline & The same & 6 & 4.7 & 10 & 7.8 & 2 & 1.6 \\
\hline
\end{tabular}

Source: Field survey, 2017.

\subsubsection{Impact on Forest Production}

Inappropriate land use changes affect their natural ecological functions and lead to a decline in land productivity and loss of biodiversity. The result from focus group discussions revealed that deforestation is an important issue in the study area and a contributor and consequence of changing weather patterns. This is because, community of the study area uses forests and forest products for many purposes; fodder, food, fuel wood, supplementary income generation and construction purposes. Likewise, tree planting (reforestation) does not seem to be a common activity in the study areas due to rain problem and coping strategies undertaken by communities in times of drought such as firewood and charcoal selling, cutting trees for feeding their livestock were led to deforestation. Hence, the respondents were using different tree species for construction material and fuel wood and charcoal production as it is the main source of energy for most of the rural people of the study area. Moreover, the focus group discussions were stated that the rate of deforestation due to demographic factors and drought problem is at an increasing rate. As a result, continued deforestation in the study area has contributed to soil erosion and land degradation which is commonly affected their livelihood strategies of the communities.

\subsubsection{Impact on Crop and Livestock Production}

Land use land cover change and deforestation can alter local climatic conditions and intensify the impacts of global climate change. Thus, drought alters the trend of forest cover throughout the study period. As a result, the communities of the study area were observed significant negative impacts of drought and reduction of natural resources such as pasture, farmland production and water sources which decreases tree growth as well as pod and leaf production. Accordingly, the livelihood occupations of the currently studied areas were 
depends both on livestock rearing and crop farming which is mixed production systems. Therefore, pasture which is the most important natural resource for rearing livestock and crop production were at reducing rates.

Hence, the productivity of the land and the livestock numbers the household owns during the study period were assessed and the descriptive results (Table 6) showed that the mean value of crop produced and livestock owned by the sampled respondents were varied in the study area among different period. Moreover, the mean values of crop and livestock production in the study area across the 30 year were declining. The result was similar to a report that states the productivity of farming crops in South Darfur State is hampered by low and declining rainfall, land and soil degradation, repeated grazing and as the result of pasture degradation, the livestock suffers due to forage deficiency, which results on the prevalence of animal diseases that negatively impacts animal production in the study area [41]. Another study also showed that the Key informants, communities, NGOs and government officials in Borana stated that the declining availability, productivity and quality of pastures (livestock) and farmland production due to shorter rainy seasons, droughts and overgrazing [40]. This indicated that, the impacts on the livelihood of the pastoralists were continuous unless natural forest resource was maintained and appropriate land use system was established..

Table 6. Respondent's crop and livestock productivity trends in study area.

\begin{tabular}{|c|c|c|c|c|c|c|c|c|c|c|}
\hline \multirow{3}{*}{ Variables } & & \multicolumn{9}{|c|}{ Crop and livestock productivity in $\mathrm{Ku}$ and numbers respectively } \\
\hline & & \multicolumn{3}{|l|}{ 1986-1996 } & \multicolumn{3}{|c|}{$1996-2006$} & \multicolumn{3}{|l|}{$2006-2016$} \\
\hline & & $\begin{array}{l}\text { Overall } \\
(\text { Mean } \pm \text { SE) }\end{array}$ & Min & $\operatorname{Max}$ & $\begin{array}{l}\text { Overall } \\
(\text { Mean } \pm \text { SE })\end{array}$ & Min. & Max. & $\begin{array}{l}\text { Overall } \\
(\text { Mean } \pm \text { SE })\end{array}$ & Min & Max \\
\hline \multirow{5}{*}{ Crop type } & Maize & $17 \pm 0.9$ & 1 & 40 & $10.4 \pm 0.52$ & 0.5 & 25 & $4.76 \pm 0.27$ & 0.5 & 12 \\
\hline & H.bean & $10.1 \pm 0.66$ & 0 & 30 & $5.91 \pm 0.36$ & 0 & 15 & $2.81 \pm 0.18$ & 0 & 8 \\
\hline & Wheat & $7.61 \pm 0.51$ & 0 & 18 & $5.24 \pm 0.36$ & 0 & 15 & $2.35 \pm 0.15$ & 0 & 6 \\
\hline & Teff & $7.74 \pm 0.47$ & 0 & 18 & $4.44 \pm 0.25$ & 0 & 10 & $2.13 \pm 0.14$ & 0 & 6 \\
\hline & Sorghum & $3.76 \pm 0.5$ & 0 & 10 & $2.57 \pm 0.37$ & 0 & 8 & $1.2 \pm 0.22$ & 0 & 5 \\
\hline \multirow{6}{*}{$\begin{array}{l}\text { Livestock } \\
\text { type }\end{array}$} & Cows & $15.5 \pm 1$ & 0 & 45 & $9.83 \pm 0.6$ & 0 & 30 & $4.7 \pm 0.3$ & 0 & 12 \\
\hline & Calves & $7.05 \pm 0.4$ & 0 & 18 & $4.34 \pm 0.3$ & 0 & 11 & $2.65 \pm 0.2$ & 0 & 8 \\
\hline & Bulls & $4.35 \pm 0.3$ & 0 & 12 & $2.79 \pm 0.2$ & 0 & 8 & $1.42 \pm 0.1$ & 0 & 4 \\
\hline & Camels & $0.73 \pm 0.2$ & 0 & 6 & $0.67 \pm 0.1$ & 0 & 4 & $0.54 \pm 0.1$ & 0 & 6 \\
\hline & Goats & $11.5 \pm 1$ & 0 & 35 & $9.71 \pm 0.7$ & 0 & 30 & $5.34 \pm 0.7$ & 0 & 55 \\
\hline & Sheep's & $4.84 \pm 0.5$ & 0 & 20 & $4.92 \pm 0.5$ & 0 & 20 & $2.62 \pm 0.6$ & 0 & 50 \\
\hline
\end{tabular}

Source: Field survey, 2017.

\subsubsection{Impact on Financial Resources}

The study found that the main financial resources that the communities of the study area depend include; livestock and livestock products, crops, forest and forest product, petty trade, casual labor force, handcraft and employment as a guard (Table 7). The result from household survey indicated that all of the rural people $(100 \%)$ depend on food crop and livestock production, both for household consumption and marketing their household expenditure during the whole different period. However, as natural resources have been over-exploited in the study area, largely as a result of recurring droughts, wood conversion, overpopulation and land use land cover change, the mean value of crop and livestock production in the study area across the 30 year were declining. This is because most of these are directly dependent on climatesensitive natural resources, such as pasture land, farmland and forests; and then their financial resources are strongly impacted by drought.

Hence, the respondents of the study area seemed to agree that diversification of financial resources and income generating activities as a key to adapting to changing conditions. As a result, about 9.6\%, 8\%, 6.4\% and $2.3 \%$ of the interviewed respondents diversified their economic activities towards petty trade, labor force in the town, selling forest product (Charcoal, fuel wood and timber) and employed as guard respectively in the recent period (Table 7). These results confirm previous studies tts.

hat states as the result of land degradation and a decline in crop production, $60 \%$ of respondents have left their agricultural land to work in the cities in building construction, brick making and water selling, as they presented better livelihood options [41]. Recurrent drought due to land use change leads to decreased pasture and water availability, which in turn leads to livestock death, reduced livestock productivity, reduced livestock disease resistance, more livestock being sold on the market, and lower livestock prices, thereby leading to weaker terms of trade and decreased household incomes. Another study also indicated that due to recurrent drought, the income generated through livestock sales are no longer sufficient, compounding poverty, food insecurity and pastoralist dropouts [40]. 
Table 7. Main source of household income of the respondents.

\begin{tabular}{|c|c|c|c|c|c|c|}
\hline \multirow{2}{*}{ Main sources of income } & \multicolumn{2}{|c|}{$1986-1996(\mathrm{~N}=128)$} & \multicolumn{2}{|c|}{$1996-2006(\mathrm{~N}=128)$} & \multicolumn{2}{|c|}{$2006-2016(N=128)$} \\
\hline & Freq & $\%$ & Freq & $\%$ & Freq & $\%$ \\
\hline Crop and Livestock Production & 128 & 100 & 128 & 100 & 128 & 100 \\
\hline Petty trade & 5 & 3.9 & 5 & 3.9 & 12 & 9.6 \\
\hline Casual labor force & 0 & 0 & 0 & 0 & 10 & 8 \\
\hline Selling forest product & 0 & 0 & 0 & 0 & 8 & 6.4 \\
\hline Handcraft & 0 & 0 & 0 & 0 & 2 & 1.6 \\
\hline Guard & 0 & 0 & 0 & 0 & 3 & 2.3 \\
\hline
\end{tabular}

Source: Field survey, 2017.

\subsubsection{Impact on Social Capital Resources}

Busa gonofa is one of the important traditional social supporting resources in the study area. These social systems are meant to support poor households or those who have lost many assets due to hazards such as droughts, conflicts or diseases. Accordingly, the results of the focus group discussions indicated that there were different mechanisms that helping the poor members of the communities of the study area during the hard time. Restocking of hazard affected households by clan members; providing milking cows and grain to hazard affected households, collection and distribution of milk to poor households; and mutual aid system where community members get together to help poor families by carry out a major task (such as cultivation or construction) in exchange for food. These showed that dealing with hazards is not a new challenge in these communities however, with droughts becoming more and more severe and frequent, these traditional supporting systems are becoming impracticable, as the number of people needing social support is increasing every year.

As a result, about $26.6 \%, 36.7$ and 67.2 of the respondents were suffering for food shortage during 1986-1996, 19962006 and 2006-2016 respectively. The study was similar to that stated social associations are negatively affected by drought impacts since incomes from livestock and livestock products and crops are highly reduced [40]. However, traditionally the Borana pastoralists have been adapting to their natural environment through access and management of communal rangelands, mobility of livestock, and mutual assistance system. Hence, the adaptation mechanism that the Borana pastoralists were used to overcome such problems was discussed in (Table 8).

Table 8. Different coping strategies of land use land cover change impacts.

\begin{tabular}{|c|c|c|c|c|c|c|}
\hline \multirow{2}{*}{ Coping strategy } & \multicolumn{2}{|c|}{$1986-1996(\mathrm{~N}=128)$} & \multicolumn{2}{|c|}{$1996-2006(N=128)$} & \multicolumn{2}{|c|}{$2006-2016(\mathrm{~N}=128)$} \\
\hline & Freq & $\%$ & Freq & $\%$ & Freq & $\%$ \\
\hline Migration & 13 & 10.2 & 22 & 17.2 & 9 & 7.1 \\
\hline Selling livestock & 3 & 2.3 & 2 & 1.6 & 14 & 10.9 \\
\hline Government support and livestock production & 1 & 0.8 & 1 & 0.8 & 4 & 3.1 \\
\hline Selling charcoal/fire wood & 1 & 0.8 & 2 & 1.6 & 3 & 2.3 \\
\hline Borrow grain/money & 1 & 0.8 & 0 & 0 & 2 & 1.6 \\
\hline Government support & 6 & 4.7 & 11 & 8.6 & 45 & 35.2 \\
\hline Migration and government support & 6 & 4.7 & 8 & 6.3 & 7 & 5.5 \\
\hline
\end{tabular}

Source: Field survey, 2017.

\section{Conclusions and Recommendations}

The present study revealed that land use land cover of the study area was at dynamic state and forests had undergone substantial changes as a result of many anthropogenic factors. Thus, the study concluded that the dynamics of forest cover and land use land cover change were caused by agricultural expansion, wood extraction, infrastructural and settlement expansion, economic factors, policy and institutional factors, social-cultural factors, demographic factor and drought problem. In conclusion, a wood extraction and drought problem appears to have been a significant factor that has impacted forest cover of the study area. However, those all factors in combinations were leading to forest cover change and land use land cover changes. Thus, change in forest cover and land use land cover were affected different livelihood strategy of the communities like; human resources, forest production, crop and livestock production, financial and their social capital resources.

Therefore, the qualitative surveys applied in this study may prove to be a useful approach for designing land use land cover change of the study areas and identify the major causes of forest cover change which was increasingly helpful in sustainable forest management. To ease the present human influence on forest and for future forest management on a sustainable basis, the following recommendations were made:

Participatory forest management programs need be strengthened so that local communities assume responsibility for the management and conservation of the forest, and remain as the beneficiaries these activities

Awareness need be given on the multipurpose use of forest resources and forest ecosystems

Natural regeneration of species in the forest can be facilitated through reduced grazing (browsing) pressure 
Training need to be given for the community to diversify their financial resources to minimize dependency on forest and thereby minimize the impact of forest and land use land cover changes on their livelihoods.

The planning and management of forests can be assisted with research findings, and therefore, more basic and applied research need be encouraged.

\section{Acknowledgements}

Above all, the author would like to thank the Oromia Agricultural Research Institute for giving me this chance and covering all the financial cost of this study. The authors also would like to extend gratitude Yabello Pastoral Dryland Research Center staff member for their unreserved encouragement. Special thanks also go to the Pastoralist and agro pastoralists of the study area, for sharing their wealth knowledge.

\section{Conflict of Interests}

The authors have not declared any conflict of interests.

\section{References}

[1] Houghton, R. A., 1994. The Worldwide Extent of Land-Use Change. Bioscience, 44 (5), pp. 305-313.

[2] Rudel, T. K., Coomes, O. T., Moran, E., Achard, F., Angelsen, A., Xu, J. and Lambin, E., 2005. Forest transitions: towards a global understanding of land use change. Global environmental change, 15 (1), pp. 23-31.

[3] FAO (Food and Agricultural Organization), 2001. Global forest resources assessment (FRA 2000): main report, FAO for. Pap. 140, Rome

[4] FAO (Food and Agricultural Organization), 2010. Global Forest Resources Assessment Main report Rome.

[5] Berhan, G., 2005. Effects of Human Activities on Forests of Dry land of Western Ethiopia. Dryland Biodiversity. Issue No 6.

[6] EFAP (Ethiopian Forestry Action Program), 1993. Ethiopian Forestry Action Program: The Challenge for Development, Vol II. Ministry of Natural Resources Development and Environmental Protection, Addis Ababa.

[7] Mohammed, H. Y., 2014. The Influence of Land Use and Cover Changes on the Pastoral Rangeland Systems of Southern Ethiopia: How Much Woody Cover is Enough?.

[8] Lambin, E. F., Geist, H. J. and Lepers, E., 2003. Dynamics of land-use and land-cover change in tropical regions. Annual review of environment and resources, 28(1), pp.205-241.

[9] Leh, M., Bajwa, S. and Chaubey, I., 2013. Impact of land use change on erosion risk: an integrated remote sensing, geographic information system and modeling methodology. Land Degradation \& Development, 24 (5), pp.409-421.

[10] Daye, D. D. and Healey, J. R., 2015. Impacts of Land-Use Change on Sacred Forests at the Landscape Scale. Global Ecology and Conservation, 3, pp.349-358.
[11] FAO (Food and Agricultural Organization), 2000. WatershedL. The electronic workshop on land-water linkages in rural watersheds, Electronic workshop.

[12] Bewket, W., 2002. Land Cover Dynamics since the 1950s in Chemoga Watershed, Blue Nile Basin, Ethiopia. Mountain Research and Development, 22 (3), pp.263-269.

[13] Reid, R. S., Kruska, R. L., Muthui, N., Taye, A., Wotton, S., Wilson, C. J. and Mulatu, W., 2000. Land-use and land-cover dynamics in response to changes in climatic, biological and socio-political forces: the case of southwestern Ethiopia. Landscape Ecology, 15 (4), pp.339-355.

[14] Elias, M., Hensel, O., Richter, U., Hülsebusch, C., Kaufmann, B. and Wasonga, O., 2015. Land conversion dynamics in the Borana rangelands of Southern Ethiopia: an integrated assessment using remote sensing techniques and field survey data. Environments, 2(1), pp.1-31.

[15] Slingenberg, A., Braat, L., Van Der Windt, H., Rademaekers, K., Eichler, L. and Turner, K., 2009. Study on understanding the causes of biodiversity loss and the policy assessment framework 1-206.Report to the European Commission Directorate-General for Environment, ECORYS Research and Consultation, the Netherlands.

[16] Campbell, D. J., Lusch, D. P., Smucker, T. A. and Wangui, E. E., 2003. Root Causes of Land Use Change in the Loitokitok Area, Kajiado District, Kenya.

[17] Garedew, E., Sandewall, M., Söderberg, U. and Campbell, B. M., 2009. Land-use and land-cover dynamics in the central rift valley of Ethiopia. Environmental management, 44 (4), pp.683-694.

[18] Mesele S, Gebrekidan H, Gizachew L, Coppock DL (2006). Changes in land cover and soil conditions for the Yabello District of the Borana Plateau, 1973-2003. Research Brief 0606-PARIMA. Global Livestock Collaborative Research Support Program. University of California, Davis. 4 pp.

[19] Daniel, J., 2010. Effects of Bush Encroachment and Its Impacts on Selected Soil properties in Borana Rangeland, Ethiopia, M.Sc. Thesis, Hawasa University, WGCF \& NR.

[20] Coppock, D. L., 1994. The Borana Plateau of Southern Ethiopia: Synthesis of Pastoral Research, Development and Changes, 1980-91 (No. 5). International Livestock Centre for Africa, Addis Ababa, p. 374.

[21] Zeleke, A. A., 2009. Bush Encroachment and Its Impacts on Plant Biodiversity in the Borana Rangeland.

[22] Angassa, A. and Oba, G., 2008. Effects of Management and Time on Mechanisms of Bush Encroachment in Southern Ethiopia. African Journal of Ecology, 46 (2), pp.186-196.

[23] Tamene, Y., 1990. Population dynamics of the problem shrubs, Acacia dropanolobium and Acacia brevispica in the southern rangelands of Ethiopia. Master's Thesis, Univ. of New South Wales. 237p.

[24] Central Statistical Agency 2013. Federal Democratic Republic of Ethiopia. Population Projection of Ethiopia for All Regions at Woreda Level from 2014-2017. Addis Ababa.

[25] Central Statistical Agency 2016. Federal Democratic Republic of Ethiopia. Agricultural Sample Survey 2015/16 [2008 E.C.] Volume Ii. Report On Livestock and Livestock Characteristics (Private Peasant Holdings). 
[26] Kothari, C. R., 2004. Research methodology: Methods and techniques. Second edition.

[27] Solomon, M. M., 2016. Effect of Land Use Land Cover Changes on the Forest Resources of Ethiopia. International Journal of Natural Resource Ecology and Management. Vol. 1, No. 2, pp. 51-57.

[28] Helmut J. Geist \& Eric F. Lambin 2001. Land-Use and LandCover Change (LUCC) Project IV. International Human Dimensions Programme on Global Environmental Change (IHDP) V. International Geosphere-Biosphere Programme (IGBP) VI. Title VII. Collection: LUCC Report Series; 4.

[29] WBISPP, 2004. Woody Biomass Inventory and Strategic Planning Project. Forest Resources of Ethiopia. Addis Ababa, Ethiopia.

[30] Walle, T., Rangsipaht, S. and Chanprasert, W., 2011. Natural resource conservation practices of resettlers in the new resettlement areas of Amhara region, Ethiopia. Kasetsart Journal Social Science, 32, pp.297-307.

[31] Sanara, Izuru, S., Narumasa, T., Tsugihiro, W., and Shintaro, K., 2014. Graduate School of Global Environmental Studies, Kyoto University, Kyoto, Japan 2Tottori University of Environmental Studies, Tottori, Japan: The Impact of Agricultural Expansion on Forest Cover in Ratanakiri Province, Cambodia.

[32] Assefa, E. and Bork, H. R., 2014. Deforestation and Forest Management in Southern Ethiopia: Investigations in the Chencha and Arbaminch Areas. Environmental Management, 53 (2), pp.284-299.
[33] Mather, A. S., 1991. Global Forest Resources. International Book Distributors, Dehra Dun.

[34] Sands, R. 2005. Forestry in a Global Context. CABI Publishing.

[35] Geist, H. J. and Lambin, E. F., 2002. Proximate Causes and Underlying Driving Forces of Tropical Deforestation. Bioscience, 52 (2), pp.143-150.

[36] Moges, Y., Eshetu, Z., \& Nune, S., 2010. Ethiopian forest resources: Current status and future management options in view of access to carbon finances. Ethiopian Climate Research and Networking and the United Nations Development Programme, Addis Ababa. pp 30-31.

[37] Belay, S., Amsalu, A. and Abebe, E., 2014. Land Use and Land Cover Changes in Awash National Park, Ethiopia: Impact of Decentralization on the Use and Management of Resources. Open Journal of Ecology, 4 (15), p.950-960.

[38] Jacobs, M. J. and Schroeder, A. (1997) Awash National Park Management Plan: 1993-1997. EWCO, Addis Ababa.

[39] Oxfam, 2011. Briefing on the Horn of Africa Drought: Climate change and future impacts on food security. Oxfam Policy and Practice: Agriculture, Food and Land, 11 (7), pp.57-62.

[40] CARE 2009: Climate-related vulnerability and adaptivecapacity in Ethiopia's Borana and Somali communities. Final assessment report August, 2009.

[41] Bashir, M., 2012. The Impact of Land-use change on the Livelihoods of Rural Communities: A case-study in Edd AlFursan Locality, South Darfur, Sudan. 